\title{
Initial Teacher Education students' conceptualisation of inclusive education
}

\section{Moeniera Moosa}

School of Education, University of the Witwatersrand, Johannesburg, South Africa moeniera.moosa@wits.ac.za https://orcid.org/0000-0002-6231-9370

\section{Tanya Bekker}

School of Education, University of the Witwatersrand, Johannesburg, South Africa tanya.bekker@wits.ac.za

https://orcid.org/0000-0002-6052-4186

(Received: 19 May 2021; accepted: 15 November 2021)

\section{Abstract}

Policy and legislative frameworks in South Africa mandate inclusive education that, given the contextual realities of classrooms, requires teachers to be responsive to diversity. There is, however, an identified gap between policy ideals and enactment that is exacerbated by a lack of conceptual clarity regarding the nature of inclusive education and practice that is still viewed by many as being limited to considerations of special needs rather than broader considerations of diversity as well. Initial Teacher Education (ITE) has a role to play in challenging and disrupting teacher thinking to support conceptualisations of inclusive education that position teachers' responsiveness to diversity. We used the Inclusive Pedagogical Approach in Action (IPAA) Framework (Florian \& Spratt, 2013) since it focuses on inclusive pedagogy as a way of thinking about and practising inclusion to support the learning of all. We conducted the qualitative research at a public urban university in Johannesburg, South Africa with 200 third-year preservice teachers. We analysed the data by considering preservice teachers' reflections on adapting content knowledge, their thinking about learner needs, and their selection of teaching and learning strategies. Findings indicate that preservice teachers were engaging with the theoretical foundations of inclusive education; they demonstrated awareness about issues of diversity but struggled to establish learners' diverse needs and how to address these in practice. This study suggests that preservice teachers' conceptualisations of inclusive education must be given consideration and that they require robust training on how to enact inclusive pedagogy. We recommend continued support for preservice teachers in building their capacity to enhance responsiveness in inclusive practice through ITE programmes and further research.

Keywords: inclusive education, preservice teachers, planning, pedagogy, practice, conceptualisations 


\section{Introduction}

Developing inclusive education systems and schools capable of educating all learners together regardless of ability levels, (dis)ability or specific learning needs, requires (i) the development of ways of teaching that support the learning of all learners by taking into account individual differences, and (ii) that teachers tasked with such teaching be equipped with the necessary skills, dispositions, and knowledge to enact inclusive practices in the classroom (Ainscow et al., 2019). Larsen et al. (2019), however, have argued that there is a "discrepancy between inclusion as a political ideal and inclusion as a practice" (p. 1049) that impacts on the enactment of inclusion. This discrepancy stems from a lack of clarity in definitions of inclusion and in conceptualisations of inclusive practice and this results in teachers and schools struggling to enact inclusion for all learners (Larsen et al., 2019).

The challenges of enacting inclusion are illustrated in the Education for All 2000-2015: Achievements and Challenges [Global Monitoring Report] (United Nations Educational, Scientific and Cultural Organization, 2015). This report indicates that despite the international inclusive education agenda, there are still 58 million children (with and without special needs) out of school globally and, in fact, inequality in education has increased. The challenge of transforming education systems to support the inclusion of all learners has particular implications for the education of future teachers. Initial Teacher Education (ITE) programmes are an arena in which preservice teachers' conceptualisations of inclusive education that perpetuate exclusionary practices can be either disrupted or reinforced (Berry, 2008). We argue in this paper that ITE programmes in South Africa should consider how preservice teachers conceptualise inclusive education to harness the potential of ITE to disrupt rather than reproduce conceptualisations of inclusive education that fail to support the inclusion of all.

The teaching practices that most newly qualified teachers adopt are those dominant practices to which they were exposed in the school in which they begin teaching (McIntyre, 2009). The implication of this is positive in cases in which the dominant practice supports inclusion but less positive in those in which dominant practices do not. This acceptance of less positive dominant practice is unlikely to be challenged by newly qualified teachers if they have not been exposed to alternatives during their ITE. It is therefore imperative to start challenging and changing preservice teachers' views on how to respond to diverse learner needs before they find themselves in school contexts where this is not always being done. Therefore, the purpose of this study was to investigate the conceptualisations of inclusive education held by third-year preservice teachers as demonstrated by their reflection on their own inclusive practice in lesson plans based on an essay they submitted. First, we situate the work within the wider body of research on inclusive education and professional knowledge. We then discuss principles of inclusive pedagogy (Florian \& Spratt, 2013) that were used as the theoretical framework. Next, we describe the research context and process and outline the findings. Analysis of the data suggests that while third year preservice teachers demonstrated engagement with the theory of inclusive education and were demonstrating awareness in 
thinking about diversity and difference, they found it challenging to consider learners' diverse needs and work out how to address these in their planning and practice.

\section{Literature review and theoretical framework}

After discussing conceptualisations of inclusive education in general, we then focus on the ways in which conceptualisations inform teaching to enable us to consider the implications for practice and for the selection of improved teaching strategies that we then go on to discuss. We draw on existing literature to argue that the ways in which inclusive education is conceptualised has particular implications for practice and that the selection of teaching strategies that are shown to be more rather than less inclusive is necessary to enhance responsiveness to diversity.

\section{Conceptualisations of inclusive education}

Inclusive education is conceptualised differently by members of the general population, preservice teachers, and in-service teachers (Krischler et al., 2019). They found that the general population tended to conceptualise inclusive education primarily as being related solely to the education of learners with special needs. In-service and pre-service teachers, however, were more likely to have a deeper understanding of inclusive education as meeting the social and academic needs of all learners. In-service teachers were found to conceptualise inclusive education more frequently in this way than pre-service teachers. This is significant since, as Krischler et al., (2019, p. 632) found, "teachers with more in-depth understanding of inclusive education reported more positive attitudes and felt better prepared to implement inclusive practices." Clark et al (1999) asserted that in order to enact inclusive education, teachers must be given opportunities to construct the meaning of inclusion for themselves and that this can be facilitated in ITE programmes.

There is a distinction between narrow and broad definitions of the concept of inclusion (Ainscow et al., 2006). Narrow definitions focus on the inclusion of learners with special education needs. Broad definitions, however, focus on the inclusion of all learners and on how schools respond to their diversity. Armstrong et al. (2011) put forward an additional category of so-called fragmented definitions that come into existence when inclusion for all is advocated but the notion of what constitutes all is fragmented by the identification of specific groups of learners who require different or additional support.

Definitions and perspectives of inclusive education have broadened in South Africa as evidenced by a policy such as the one outlined in White Paper 6 (Department of Education, 2001) that is situated within a social model approach and that recognises a range of barriers to learning along with a broad spectrum of diversity. White Paper 6 is, however, ambiguous in its reconciliation of, on the one hand, broader perspectives of difference that recognise a range of diversity and, on the other, an exclusive, special needs placement paradigm. The introduction of what we might call a levels-of- support continuum and policy as indicated in the document, Screening, Identification, Assessment and Support (Department of Basic Education, 2014) attempts this reconciliation while unintentionally reinforcing the separate 
provisioning model of special needs resulting in that fragmented perspective on inclusion cautioned against by Armstrong and colleagues (2011). This is important in a consideration of the type of preparation for inclusive practice, supported by conceptualisations of inclusive education, that preservice teachers are receiving.

\section{Conceptualisations informing teaching}

Shifting narrow conceptualisations of inclusive education held by teachers beyond that of special needs requires engaging with teachers' views, beliefs, and thinking about inclusive education. The goal of providing equitable quality education for all learners is dependent on learners having access to transformative teachers who view diversity as a strength in teaching and learning and who enact learner-centred pedagogy that is responsive to diversity, as suggested by Akyeampong (2017). However, South African studies have consistently found that many teachers retain medicalised beliefs and views on inclusive education, and that negative attitudes towards inclusive education and the resulting continued exclusionary practices in classrooms persist (Adewumi \& Mosito, 2019; Englebrecht, 2006; Muthukrishna et al., 2016). Such evidence indicates that despite South African policy imperatives, "teachers find it difficult to make a shift from their current beliefs about what constitutes best inclusive teaching practice" (Makoelle, 2014, p.188). We argue that if teachers are to be supported to make a shift in thinking, ITE has an important role to play in exposing preservice teachers to reflective activities that allow them to engage with their current beliefs and provide them with opportunities to challenge and shift their thinking about inclusive education in order to bring about social change.

Christie (2018) suggested that preservice teachers come into ITE programmes with a common-sense understanding of teaching. This needs to be challenged and developed into professional knowledge and requires refinement of their critical reflection. Sayed et al. (2018) have explained that professional knowledge development is a key focus of ITE and have argued for three knowledge sets to frame this development.

The first knowledge set connects specialist, specific, and general knowledge to teaching and learning in a particular subject, learning domain, or discipline. Subject content knowledge (knowledge of the content of the subject), pedagogical content knowledge (knowledge of how to organise content for effective learning), and general pedagogical knowledge (general management of learning that is not necessarily subject specific) are included in this knowledge set. The second knowledge set refers to knowledge external to a particular subject, learning domain, or discipline including curricula knowledge, knowledge about context, and knowledge about the aims and purposes of education. This knowledge set enables the effective teaching of a particular subject, learning domain, or discipline. The third knowledge set focuses on the affective dimensions of teaching and refers to both technical skills and value dispositions teachers need to act as agents for social justice. The third knowledge set works across and with the other two knowledge sets as the content teachers teach, the manner in which they teach it, and their understanding of the context in which they teach and act as agents comes together (Sayed et al., 2018). The primary source of these 
knowledges is the Minimum Requirements for Teacher Qualifications (MRTEQ) (Republic of South Africa, 2015).

In relation to inclusive education, we argue that these three knowledge sets conceptually frame ITE to support the development of teacher agency in relation to inclusion alongside the development of inclusive pedagogy for and across specific subjects in particular contexts to enable teachers to "change the status quo and develop social justice and inclusion" (Pantić \& Florian, 2015, p. 333).

The role of ITE in developing knowledge sets of preservice teachers and in supporting the development of broader conceptualisations of inclusive education is therefore an important focus if preservice teachers are to be equipped to enact inclusive practice. ITE programmes, in developing these knowledge sets, have the potential to enable shifts in thinking from those common-sense understandings to informed and critical reflection on social realities of the context within which preservice teachers are being prepared to engage (McIntyre, 2009; Walton \& Rusznyak, 2020). We argue that it must be borne in mind that shifts in thinking do not in and of themselves guarantee a shift in practice. However, a shift in practice is not likely to be possible at all without a shift in thinking. It is for these reasons that we focus on third-year preservice teachers' conceptualisations of inclusive education after their completion of an inclusive education module to understand the ways in which these students are able to reflect on their own practice and recognise practices that are more or less inclusive. We were particularly interested in exploring how preservice teachers conceptualise inclusive education and think about the importance of adapting content knowledge, what they think about learner needs, and how they select teaching and learning strategies.

\section{Adapting content knowledge}

The content knowledge taught to learners in South African schools is mandated by the national Curriculum and Assessment Policy Statement (CAPS) (Department of Education, 2011). The curriculum specifies the content to be taught in each learning area per grade as well as determining the pace at which this content should be taught and how it should be assessed. However, in order to teach content knowledge effectively, teachers themselves require sound knowledge of the subject. Content knowledge refers to the amount of knowledge that the teacher has and the way in which that knowledge is organised in their mind.

The participants of this study had been introduced to Shulman's (1986) concept of Pedagogical Content Knowledge (PCK) along with subject knowledge, pedagogical knowledge, and general pedagogical knowledge in their first year of study. PCK allows subject content knowledge to find expression in the lesson since it is in this domain that understanding of content, understanding of how best to make that content accessible to learners, and the understanding of learners themselves are brought together. Acquisition of PCK is supported, developed, and enhanced through practical experience and reflection on that experience (Shulman, 1986). Informing PCK is curricular knowledge (both lateral and vertical) that relates to knowledge of curriculum organisation, how the curriculum of a 
particular subject relates to the curriculum in other subjects, representation, and requirements of particular subjects at specific grade levels, and how this articulates with grades above and below.

White Paper 6 (Department of Education, 2001) suggested that the process of teaching and learning needs to be flexible enough to meet the needs of individual learners if the curriculum itself is not to become a barrier to learning. Curriculum adaptation refers to the modification of curriculum to meet diverse learning needs in the classroom. The type of teacher thinking that assumes that all learners are different and have different learning needs at particular points in time (Florian \& Black-Hawkins, 2011) creates opportunities for responsive teaching in which content is adapted to suit the needs of learners as they are evidenced in particular lessons. This is significant to the study since preservice teachers were asked to reflect on their lesson plans and these reflections provided us with insight into the conceptualisations of inclusive education suggested in the decisions made in relation to adapting content knowledge.

\section{Thinking about learners' needs}

MRTEQ (Republic of South Africa, 2015) notes that "inclusive education forms an important aspect of both general pedagogical knowledge and specialised pedagogical knowledge" ( $p$. 11). Furthermore, the basic competencies for beginner teachers include being able to understand diversity "in order to teach in a manner that includes all learners" (p. 56). Additionally, the National Curriculum and Assessment Policy Statement National Curriculum Statements (Department of Basic Education, 2011) promotes a learner centred approach that necessitates consideration of the context of learners. In the inclusive education module taught to this specific cohort of third year preservice teachers, we engaged with their recognition of diversity in terms of race, religion, language, culture, gender, socio-economic background, dis/ability, and learning ability. This is in line with the South African Council of Educators' (SACE) Code of Professional Ethics that suggests that teachers should be responsive to "the uniqueness, individuality, and specific needs of each learner" (South African Council of Educators, 1997, p. 2).

A medicalised approach to thinking about learner needs would involve adopting a normative stance and would identify learners with particular needs as being different from those of the majority and who would therefore require specialised pedagogical intervention. In contrast, Florian and Black-Hawkins (2011) advocated for an inclusive pedagogy for all with the acknowledgment that there will be individual differences. These scholars conceptualised this as the provisioning of rich learning opportunities for all at the same time, so that "instead of providing something different or additional for children who experience difficulties in their learning, inclusive pedagogy seeks to extend what is ordinarily available to everybody" ( $\mathrm{p}$. 813). This requires recognising pedagogically significant difference and responding pedagogically to this by making support available within the lesson that can be accessed by all learners. For example, recognising as a pedagogically significant difference that not all learners are English first language speakers and responding pedagogically by providing language support that is accessible to all could be part of the general lesson. This is 
significant to this study since we looked at preservice teachers' lesson plan reflections to gain insight into the conceptualisations of inclusive education that were apparent in the decisions they made in thinking about learner needs.

\section{Using teaching and learning strategies for inclusive education}

In order to be responsive and effective, teachers need to have a broad repertoire of teaching and learning strategies. Inclusive pedagogical strategies discussed in this section include the concept of universal design for learning, differentiation, and strategies such as cooperative learning. This is by no means a full list, but these serve as examples of the types of inclusive teaching and learning strategies with which this cohort of third year preservice teachers engaged in their course work. The reason for the selection of universal design for learning, differentiation, and co-operative learning as strategies for discussion is that these were recognised as dominant strategies associated with inclusive practice in Morina's (2020) extensive literature review.

Universal design for learning recognises that the ways in which individuals learn differ and that teachers should, in their planning and teaching, consider many different means of representation, expression, and engagement on the principle of accessibility for all (Bedrossian, 2019; Hall et al., 2012). This means that instead of planning a lesson first and thinking later about any accommodations and or adaptations for individual learners, lessons that include ways in which support and scaffolding can be built into them to support the learning of all, are planned (Coy, 2016). Kameenui et al. (2002, p. 7) presented six universal design principles, discussed throughout the book, that support planning lessons that enable diverse learners to gain cognitive access to the curriculum. The first principle is a focus on "Big Ideas" that are the fundamental concepts and principles that guide decisions on what to teach. The second is attention to "Conspicuous Strategies" that are the steps for solving problems or accomplishing a task. Third, "Mediated Scaffolding" draws attention to varying levels of temporary support and assistance provided to support the learning of all. The fourth principle is accessing "Primed Background Knowledge" or prerequisite skills and knowledge needed for a new task. The fifth principle of "Strategic Integration" that involves integrating essential knowledge and skills to facilitate higher level thinking skills. Last, "Judicious Review" provides opportunities for learners to review important learning at different points in the learning cycle. These principles support the learning of all learners in the class by structuring into lesson planning many pathways and opportunities for the cognitive engagement of all.

Differentiated teaching is another example that affords teachers the opportunity to plan, teach, and assess at different levels of difficulty and to meet the needs of all learners (McTighe \& O'Connor, 2005; Thomlinson, 2003). The distinction between the concept of universal design for learning and differentiated teaching lies in the core purpose. The purpose of the former is to proactively and broadly plan from the beginning for many means of ensuring full participation of all. The purpose of differentiated teaching is more specifically and narrowly a focus on providing instruction and assessment for different levels of task and content complexity. Content knowledge enables understanding of levels of cognitive 
complexity associated with the concept to be taught so that thoughtful differentiations can be selected. Ideally, all learners work on the same concept or content in a lesson but with differentiated instruction and activities designed to maximize their engagement (McTighe \& O'Connor, 2005). A traditional means of using differentiation is to sort learners into ability groups labelled as more or less able. In contrast, inclusive differentiation avoids exclusionary practice in the form of labelling and "becomes a valuable strategy for supporting the learning of everyone when it is used in an 'elastic and creative' way rather than as a 'simplistic linear' means of sorting pupils into more or less able" (Nind, 2005, p. 4). This can, for example, be achieved by providing tiered activities that require all learners to engage with key concepts but that offer increasing levels of scaffolding to support that engagement. Differentiation has been critiqued, however, for its potential to single out some learners for something that presents as different to others and that carries, therefore, the potential of marginalisation and labelling (Florian, 2015; Pappano, 2011)

Co-operative learning is a strategy that can be used when tasks require problem solving that may benefit from collaborative learning efforts as Sharan (2010) has pointed out. With cooperative learning learners facilitate each other's learning and improve social, communication, thinking, and language skills as well as come to appreciate each other as diverse individuals. Active participation is a key principle and requires that teachers plan carefully structured tasks. This allows an opportunity for teachers to be responsive in their design of the task because the possibilities for different components of tasks that consider the individual needs of learners within the group are endless. Putnam (2009) described positive interdependence, individual accountability, cooperative skills, simultaneous interaction, and group reflection as key principles of co-operative learning. While these principles of cooperative learning create conditions for improving communication skills and enhancing critical thinking and problem-solving in collaborative ways, Putnam (2009) suggested that is important to avoid the type of group work during which some do the work and others remain uninvolved.

Loreman (2017, p. 3) pointed out that strategies such as universal design for learning, differentiation, and co-operative learning share a common lack of prescription since "the majority of inclusive pedagogical approaches are based on principles and strategies that the teacher must then adopt and adapt to the situation." He argued that this requires far more of teachers than merely following a prescriptive checklist of teaching tips and could therefore be viewed as a drawback but noted that it can also be viewed as enhancing capacity for teacher agency. By exposing pre-service teachers to a range of inclusive strategies such as the above we hope that they are enabled to select teaching and learning strategies that include rather than exclude. This is significant to this study since we considered preservice teachers' lesson reflections to give us insight into the conceptualisations of inclusive education suggested by the decisions they made regarding using teaching and learning strategies.

\section{Theoretical framework}

Florian et al. (2013), advocated that the Inclusive Pedagogical Approach in Action (IPAA) framework for Inclusive Pedagogy be used both in and outside ITE programmes in order to 
support the development of inclusive education in different contexts. This argument provides justification for the use of IPAA as a theoretical framework for this study. IPAA is based on three key principles that relate to particular ways of thinking or beliefs about inclusive education. The first of these principles is that difference must be accounted for as an essential aspect of human development in any conceptualisation of learning. Teachers who hold this conceptualisation of difference have been shown to be more likely to adapt their teaching to accommodate individual differences (Campbell et al., 2003; Forlin, 2010). IPAA promotes responses to difference that are inclusive of all learners and rejects any strategies that exacerbate difference (Florian, 2014). However, inclusive pedagogy does not deny difference in learners' learning but advocates responding to difference in a way that does not marginalise any learners (Florian, et al., 2013) by building the capacity of teachers to exercise professional judgement in deciding on appropriate ways of meeting learner needs while considering how their pedagogical choices will affect all learners in the class. To this end IPAA describes a range of inclusive strategies (Florian, 2014), such as differentiation and cooperative learning described in the previous section, that are relevant to this study.

The second IPAA principle is that teachers must believe they are capable of teaching all learners. Florian (2008) contended that teachers have the capability to teach children with diverse needs but lack confidence in their ability to do this. A strong predictor of preservice teachers' positive attitudes towards inclusion is their level of confidence in working in inclusive environments (Forlin et al., 2009). Associated with the assumption that teachers believe themselves capable of teaching all learners is the view that difficulties in learning are considered professional challenges for the teacher and that responding to these challenges requires commitment to supporting the learning of all (Florian, 2014). This principle challenges the common view that undermines teacher confidence to work in inclusive classrooms, namely that meeting special education needs requires special teaching that ordinary teachers cannot do (Campbell et al., 2003). This is significant for this study since we engaged with third-year pre-service teachers' conceptualisations of inclusive education and reflections on their own lesson plans for insight into ways in which they conceptualise inclusive education and into their feelings of capacity and/or responsibility for inclusive practice.

The third IPAA principle stresses the importance of continual professional learning and developing new strategies for working with others. It is acknowledged that teachers need support in developing their understanding of inclusive pedagogy and how to enact this in the classroom (Florian et al., 2013). Teacher collaboration as an example of this support is widely accepted as key to implementing inclusive education (Ainscow, 2014). In addition, inclusive practice also encompasses the collaboration of teachers with parents, guardians, support professionals, and other stakeholders (Forlin et al., 2009). In this study we asked preservice teachers in what ways they feel their lessons were more or less inclusive and we then use these reflections to explore what they draw on either individually or collaboratively in their professional learning that supports their inclusive practice. 


\section{Research methods}

The purpose of this research was to explore third-year pre-service teachers' conceptualisations of inclusive education based on an essay they submitted. A qualitative interpretivist case study research approach (Creswell, 2007) was most suitable because it allowed for an in-depth understanding of participants' conceptualisations. This approach facilitated gathering a rich description of students' explanations of what inclusion is and what it is not. The purpose of this paper is not to account for contextual constructions of inclusion although we acknowledge that participants' conceptions of inclusion have been socially constructed based on their experiences in various classroom contexts during teaching practice, and on their own backgrounds and school experiences.

We note that a weakness of using a qualitative research design is that the findings cannot be generalised. We have attempted to compensate for this weakness by including a sample of preservice teachers across different phases and subject specialisations in this study. Another identified limitation of this study is that by using essays as the data source, we were not able to probe participant understanding or ask for clarification of views as would have been possible in interviews.

\section{Context of the study}

This research was conducted at a large comprehensive public urban university in Johannesburg, South Africa. All third-year students at the institution complete a compulsory six-week module in inclusive education that includes reference to global and national definitions, historical development, philosophical and pragmatic underpinnings, national policy, and inclusive pedagogy. The essay assessment of this course required students to select and reflect on one lesson plan prepared for their teaching practice and to draw on course material to indicate to what extent, if any, their selected lesson was inclusive. These essays revealed that some student conceptions were accurate, others not, and that some demonstrated serious misunderstandings of what inclusion is despite having attended the module.

\section{Research questions}

Based on the responses we noted from the students' essays we developed the following overall research question for this study. "How do third-year Education students conceptualise inclusive education as demonstrated by reflection on their lesson plans?" This question is guided by the following sub-questions:

- Why do these third-year students feel that their lessons were inclusive?

- Why do these third-year students feel that their lessons were not inclusive?

The aim of this research was to explore the conceptualisations of inclusive education that this group of third-year preservice teachers had in relation to their reflections on how they had planned and implemented their lessons. 


\section{Data collection}

Third-year students were required to submit an essay that formed part of their course work. Participants were purposively and conveniently (Creswell, 2007) selected since they were all full-time third-year students registered for a Bachelor in Education degree. From the total cohort of 580 third year students, 200 students gave consent for their essays to be analysed. Participants included students from the Foundation (FP), Intermediate (IP), Senior (SP), and Further Education and Training (FET) phases. Table 1 indicates the distribution of participants across phases.

\section{Table 1}

Number of participants across phases

\begin{tabular}{|l|l|l|}
\hline Phase & $\begin{array}{l}\text { Number of } \\
\text { participants } \\
\text { per phase }\end{array}$ & $\begin{array}{l}\text { Percentage of } \\
\text { participants in each } \\
\text { phase }\end{array}$ \\
\hline Foundation Phase (Grades 1-3) & 33 & $16 \%$ \\
\hline Intermediate Phase (Grades 4-6) & 38 & $19 \%$ \\
\hline Senior Phase (Grades 7-9) & 72 & $36 \%$ \\
\hline FET (Grades 10-12) & 57 & $29 \%$ \\
\hline Total & 200 & $100 \%$ \\
\hline
\end{tabular}

Informed consent was acquired after the essays had been marked and the marks were officially published at the end of the academic year in 2018. In this way no student could feel that their participation or non-participation in this study would have consequences on their overall academic results. Participants were asked to submit copies of their marked assignments by placing them in a designated sealed box after removing the identifying cover sheet to ensure anonymity and confidentiality. Subjects taught in particular phases were determined by details provided in their lesson plans.

Numeracy as a subject was selected by most FP students, a decision for which we cannot account. Natural Science as a subject was selected by most IP and SP students which may have been because Natural Science has the highest number of registered students in these phases at this particular institute. English as a subject also has the highest number of registered students in the FET phase at this particular institute and was selected by most participants.

\section{Data analysis}

We analysed the data deductively using the sections indicated in the particular university's lesson plan format. We considered the sections of the lesson plan that dealt with content knowledge, thinking about learner needs, and teaching and learning strategies as core components in relation to the participant's conceptualisation of inclusive education. Based on this we noted participants' consideration of each of these aspects in relation to how their lesson was inclusive (see table 2). 


\section{Trustworthiness and credibility of the study}

To ensure trustworthiness, the data was analysed independently by the two researchers. We then discussed and compared the categories in order to reach "intercoder agreement" (Nunan $\&$ Bailey, 2009, p. 428) and this enhanced the trustworthiness and credibility of the findings. We immersed ourselves in the data by reading and examining students' responses in their essays. We then followed the process of crystallisation to identify and articulate patterns and themes that we noticed. We do not view collecting data at one ITE institution as a limitation but, instead, view this as an opportunity to develop an in-depth understanding of students' conceptualisation of inclusive education as demonstrated by reflection on their lesson plans. However, we do note that the findings may not be applicable to other contexts. We therefore recommend that more research be conducted on the aspect of preservice teacher's conceptualisations of inclusive education and pedagogy at other initial teacher education institutes.

\section{Findings and discussion}

We structure the discussion of the findings using the categories we used for data analysis: adapting content knowledge; consideration of learner needs; and teaching and learning strategies. Under each category, the research sub-questions of why these third-year students feel that their lessons were inclusive and of why they feel that their lessons were not inclusive are considered. We discuss how third year students conceptualised their lessons in relation to what they felt made their lessons inclusive or not under the subcategories of how they adapted content knowledge, what aspects of learner needs they considered, and which teaching and learning strategies were used in their lessons.

Table 2

Participants overall responses

\begin{tabular}{|c|l|l|l|l|l|l|}
\hline \multirow{2}{*}{} & \multicolumn{3}{|l|}{$\begin{array}{l}\text { Why do third years feel their lessons were } \\
\text { inclusive? }\end{array}$} & \multicolumn{2}{l}{$\begin{array}{l}\text { Why do third years feel their lessons were } \\
\text { not inclusive? }\end{array}$} \\
\cline { 2 - 7 } & $\begin{array}{l}\text { Adapting } \\
\text { content } \\
\text { knowledge }\end{array}$ & $\begin{array}{l}\text { Thinking } \\
\text { about } \\
\text { learners } \\
\text { needs }\end{array}$ & $\begin{array}{l}\text { Teaching } \\
\text { and learning } \\
\text { strategies }\end{array}$ & $\begin{array}{l}\text { Adapting } \\
\text { content } \\
\text { knowledge }\end{array}$ & $\begin{array}{l}\text { Thinking } \\
\text { about } \\
\text { learners' } \\
\text { needs }\end{array}$ & $\begin{array}{l}\text { Teaching } \\
\text { and learning } \\
\text { strategies }\end{array}$ \\
\hline $\begin{array}{l}\text { Foundation } \\
\text { Phase } \\
\text { (Grades 1-3) } \\
\text { n=33 (16\%) }\end{array}$ & 13 & 24 & 26 & 5 & 22 & 22 \\
\cline { 2 - 7 } & $39 \%$ & $73 \%$ & $79 \%$ & $15 \%$ & $67 \%$ & $67 \%$ \\
\hline $\begin{array}{l}\text { Intermediate } \\
\text { Phase } \\
\text { (Grades 4-6) } \\
\text { n=38 (19\%) }\end{array}$ & 17 & 34 & 30 & 7 & 24 & 25 \\
\cline { 2 - 7 } & $45 \%$ & $89 \%$ & $79 \%$ & $18 \%$ & $63 \%$ & $66 \%$ \\
\hline
\end{tabular}




\begin{tabular}{|c|c|c|c|c|c|c|}
\hline \multirow{2}{*}{$\begin{array}{l}\text { Senior Phase } \\
\text { (Grades 7- } \\
9) \\
\mathrm{n}=72(36 \%)\end{array}$} & 28 & 60 & 56 & 12 & 36 & 34 \\
\hline & $39 \%$ & $83 \%$ & $78 \%$ & $17 \%$ & $50 \%$ & $47 \%$ \\
\hline \multirow{2}{*}{$\begin{array}{l}\text { FET (Grades } \\
10-12) \\
\mathrm{n}=57(29 \%)\end{array}$} & 17 & 49 & 42 & 14 & 29 & 28 \\
\hline & $30 \%$ & $86 \%$ & $74 \%$ & $25 \%$ & $51 \%$ & $49 \%$ \\
\hline \multirow{2}{*}{$\begin{array}{l}\text { TOTAL } \\
\mathrm{n}=200\end{array}$} & 75 & 167 & 154 & 38 & 111 & 109 \\
\hline & $38 \%$ & $84 \%$ & $77 \%$ & $19 \%$ & $56 \%$ & $55 \%$ \\
\hline
\end{tabular}

\section{Adapting content knowledge}

In terms of what participants felt was inclusive about their lessons, they expressed the importance of adjusting lesson content to accommodate and recognise learners' diverse academic needs. This included the recognition of learner's access to content knowledge, having clear lesson outcomes, and a consideration of language barriers. Participants foregrounded lesson outcomes that would include all learners by looking "at the purpose of the lesson and [coming] up with key questions and the skills the learners must develop at the end of the lesson" (FET, Grade 10, Geography). Lesson content was adapted by participants in that they "attempted to accommodate the individual needs of each learner by using analogues, images and demonstrations to help allow epistemological access" (FET, Grade 10, Physical Science). Participants stated that it was necessary to make "instructions as simple as possible, providing key vocabulary and definitions with examples which are relevant" (SP, Grade 8, Geography). Furthermore, "the choice for examples used were sensitive not to be offensive to the diversity of learners" (FET, Grade 10, Physical Science).

Content was adapted by "breaking down tasks into manageable chunks." Another participant indicated, "I introduced new content and new vocabulary that learners are unfamiliar with by discussing and explaining. I used scaffolding, reading together with learners for information and looking also to the misunderstandings learners might have during the lesson" (SP, Grade 8, Geography). Significantly, a participant stated, "[I] realised before presenting the lesson [that] learners [had] different cognitive capabilities and they will therefore work at different paces" (SP, Grade 9, English).

In thinking about ways in which their lessons were not inclusive, participants indicated that their lessons had not considered learner diversity adequately, lessons lacked scaffolding, and, at times, inappropriate examples were used which excluded learners. An example is the statement,

I did not demonstrate responsiveness to diversity because my pedagogical choice did not acknowledge and value differences based on gender and socioeconomic context . . . I did not provide a variety of options. Basically, teaching everyone does not give the 
same support and does not result in responsiveness that meet[s] the needs of all learners. (IP, Grade 5, English)

One participant acknowledged, "I can see that my pedagogical content knowledge is insufficient. I did not consider the differences of my learners, by doing this I excluded many. I also excluded some by thinking that all learners have common prior knowledge" (IP, Grade 6, Maths). Another participant noted, "I formulated a bell curve form of thinking which considered the average learners and overlooked the learners on the ends of the curve." (IP, Grade 6, Natural Science). This is supported by the participant who noted, "I gave all the learners the same amount of time to complete the task regardless of the cognitive abilities. I explained the concept to them as if all of them were familiar with English" (SP, Grade 9, English). Participants reflected critically on the views they held and one stated, "As teacher I upheld certain deterministic views about learning because I did not focus on what my learners could and could not do but presented the lesson either way" (FET, Grade 10, English).

Positive examples here demonstrate that participants are thinking about adapting content to meet the needs of learners and not merely thinking about teaching to the middle group as associated with bell curve thinking (Florian \& Walton, 2017). There are indications that participants were planning from the beginning to consider ways of adapting content, accommodate for difference, and scaffold understanding and that they were able to recognise in what ways their lessons are not inclusive. What is of concern is that this is the area considered by the least number of participants overall which suggests that adapting content is starting to be but is not yet fully integrated into third-year pre-service teachers' conceptualisations as a key component of inclusive education.

\section{Thinking about learner needs}

In terms of what made their lessons inclusive participants focused specifically on learners' cognitive, language, cultural, and socio-economic needs and being responsive to these when planning and presenting their lessons. Many participants felt that learners' challenges with "language [as] a huge barrier" needed to be taken into account. In addition, participants noted that "learners are from different ethnic groups and therefore [a teacher] could not code switch in order to not exclude any learners from the lesson" (FET, Grade 10, Geography). With regard to responsiveness to learners' needs, participants "felt the responsibility to go back to the topic the following week. [They] noticed that the children in [their] class were different individuals." In addition, participants "built a bridge between what the learners know and what they face on a daily basis" this was done "to create a learner friendly environment so that all learners would be active participants in the lesson" (FET, Grade 10, Geography).

In contrast, when considering what made their lessons not inclusive participants noted that they had considered only limited aspects of learner diversity; a participant stated,

my lesson did not adhere to inclusive principles in a sense that I saw all the learners in my class as homogenous. I did not take into consideration that difficulties learners 
experience in learning. The lesson was not responsive to learners' diversity rather it turned a blind eye to it (IP, Grade 5, History).

Participants raised concerns about not being able to meet learners' language needs during lessons since learners come

from different linguistic backgrounds . . . I did not make an extra effort to accommodate them. I just incorporated a one size fits all approach without addressing the language barrier, and this might have constrained epistemological access to some learners because of the pedagogical choices I made leading to them not fully accessing knowledge. (SP, Grade 9, Geography)

Another concern raised was about perceived lack of capacity to be fully responsive to all needs as seen in this statement:

I felt helpless and that there was nothing I could do . . . with regards to disability, I was unable to accommodate a learner with a learning disability; I excluded him from lessons . . . I wouldn't even ask [for] or check their books as I felt really hopeless. (SP, Grade 7, EMS).

Examples of ways in which lessons were inclusive demonstrated a shift away from medicalised thinking as participants recognised their professional responsibility to all learners in their class. This indicates that these third-year students are conceptualising inclusive education in broad rather than narrow terms since there is recognition of the range of diversity that may include disability rather than a focus on disability/special needs in particular (Ainscow et al., 2006). There is clear evidence that difference is being accounted for as an essential aspect of human development (see Florian, et al., 2013). Difference was not being spoken of in terms of disability only and diversity was being recognised. Thinking about learner needs is therefore strongly integrated in these participants' conceptualisations of inclusive education. Examples of lessons not being inclusive support this too, since participants recognised the ways in which they had not catered to learner needs. What is interesting to note here is that participants. while recognizing this, did not always feel that they had the capacity to know how to do things differently. This could account for feelings of resistance and being overwhelmed by thinking about learner needs. This is significant as Florian et al., (2013) highlighted, in that teachers need to believe they are capable of teaching all learners for inclusive education to be realized.

\section{Teaching and learning strategies}

In discussing what made their lessons inclusive, participants pointed to making a conscious decision to select various teaching and learning strategies that included cooperative learning, extending learner engagement, and differentiation. These strategies included using "a game as a revision tool for my lesson, this allowed for co-operative learning in my class" (FET, Grade 11, Geography). In addition, when selecting strategies, "the learners' background knowledge was considered. Working in pairs helped learners voice out their opinions 
between their partners in a language they all understand" (FET, Grade 10, English). Conscious decisions were made "not to divide the class into different labelled groups, but rather keep them as one" (FP, Grade 3, Numeracy).

With regard to indications of what was not inclusive participants referred to teaching and learning strategy selections that limited interaction such as using mostly "discussion and explanation" or a more teacher centred approach because of "fear that it might get too loud and uncontrollable."

Examples such as these demonstrate that participants are engaging with selecting teaching and learning strategies that have the potential to be more inclusive and are recognising less inclusive selections. Participants were mindful of attempting to avoid marginalisation and/or exclusion of learners in the classroom and instead were foregrounding the principle of accessibility for all (see Hall et al., 2012). Reflection on less inclusive choices indicated that participants were questioning ways in which they could make learning accessible for all. This suggests that teaching and learning strategies are strongly linked to the notion of inclusive pedagogy in the conceptualisations of inclusive education held by participants.

\section{Insights and implications}

The data indicated that this cohort of third-year pre-service teachers are starting to demonstrate engagement with the theory of inclusive education and have started developing individual conceptions of what inclusive education would be for them in practice. The findings also indicated, however, that while participants strongly linked thinking about learners needs to inclusive education, they struggled with how to address learners' diverse needs in their planning and practice. FP participants thought the least about learner needs but were also the most critically reflective about this when they considered what had made their lessons less inclusive. Participants across all phases had not regarded the aspect of adapting content knowledge to meet learners needs as an important component of inclusive pedagogy and this has implications for ITE programmes since thinking about content knowledge needs to be firmly grounded in conceptualisations of inclusive education if teachers are to be able to consider alternative ways of making content accessible to all. FP and IP students considered the selection of teaching and learning strategies as essential to inclusive pedagogy more than did the SP and FET students which is of concern given the content driven nature of subject teaching in the high school. Additionally, and possibly related to this, FET participants also integrated thinking about adapting content knowledge in their conceptualisations of inclusive education the least but were the highest in acknowledging this as a concern. It is evident, given these critical reflections, that participants are able to recognise inclusive and less inclusive aspects of their lessons, that they have an understanding of the principles of inclusive pedagogy, and that this supports conceptualisations of inclusive education. Participants do, however, feel a lack of confidence most of the time in their ability to translate this understanding into practice. These findings suggest that continued support in building capacity to enhance responsiveness and inclusive practice is required and needs to be addressed in ITE programmes and in future research. 


\section{Conclusion}

In conclusion, we argue that ITE has a role to play in challenging and disrupting teacher thinking to support conceptualisations of inclusive education in South African classrooms specifically based on the need for inclusive practice. When preservice teachers are able to engage with the theory of inclusive education as well as with ideas of learner difference they will be in a position, theoretically, to be responsive to learners' diversity. This indicates the importance of exposing preservice teachers to aspects of inclusive pedagogy that would transform their thinking about what inclusive education really means. Poor conceptualisation of inclusive education would impact on ensuring that good quality education is provided for all in order to respond effectively to issues of learner diversity and access in the South African classroom. We recommend that further research be conducted on South African preservice teachers' conceptualisations of inclusive education in diverse contexts in order to gain more insights into how ITE programmes can better support prospective teachers. In addition, we also recommend that inclusive education theory be embedded in all ITE programmes so that all teaching is considered to be inclusive and not something separate or optional.

\section{References}

Adewumi, T. M., \& Mosito, C. (2019). Experiences of teachers in implementing inclusion of learners with special education needs in selected Fort Beaufort District primary schools, South Africa. Cogent Education, 6, 1-20.

Ainscow, M., Booth, T., \& Dyson, A. (2006). Improving schools, developing inclusion. https://core.ac.uk/download/pdf/309634.pdf?repositoryId=3

Ainscow, M. (2014). From special education to effective schools for all: Widening the agenda. In L. Florian (Ed.), The Sage handbook of special education (pp. 172-185). Sage.

Ainscow, M., Slee, R., \& Best, M. (2019). Editorial: The Salamanca Statement: 25 years on. International Journal of inclusive education, 23(7/8), 671-676.

Akyeampong, K. (2017). Teacher educators' practice and vision of good teaching in teacher education reform context in Ghana. Educational Researcher, 46(4), 194-203.

Armstrong, D., Armstrong, A. C., \& Spandagou, I. (2011). "Inclusion: By choice or by chance?" International Journal of inclusive education, 15(1), 29-39.

Bedrossian, L. (2019). Understand and promote the use of Universal Design for Learning in higher education. Disability Compliance for Higher Education, 23(10), 7-17.

Berry, R. A. (2008). Novice teacher's conceptions of fairness in inclusion classrooms. Teacher and Teacher Education, 24(5), 1149-1159. 
Campbell, J., Gilmore, L., \& Cuskelly, M. (2003). Changing student teachers' attitudes towards disability and inclusion. Journal of Intellectual and Developmental Disability, 28(4), 369-379.

Christie, P. (2018). Foreword. In Y. Sayed, N. Carrim, A. Badroodien, Z. Macdonald, \& M. Singh, M. (Eds.), Learning to teach in post-apartheid South Africa: Student teachers' encounters with Initial Teacher Education (pp xxiii-xxvi). African Sun Media.

Clark, C., Dyson, A., Millward, A., \& Robson, S. (1999). Theories of inclusion, theories of schools: Deconstructing and reconstructing the 'inclusive school'. British Educational Research Journal, 25(2), 157-177.

Coy, K. (2016). Post-secondary educators can increase educational reach with Universal Design for Learning. Educational Renaissance, 5(1), 27-36.

Creswell, J.W. (2007). Qualitative inquiry and research design: Choosing among five approaches. Sage.

Department of Education. (2001). White Paper 6: Special Needs Education: Building an inclusive education and training system, in South Africa. Government Printer.

Department of Education. (2011). Curriculum and Assessment Policy Statement. Grades 4-6, Natural Sciences. Government Printer.

Department of Basic Education. (2014). Policy on Screening, Identification, Assessment and Support. Government Printer.

Engelbrecht, P. (2006). The implementation of inclusive education in South Africa after ten years of democracy. European Journal of Psychology of Education, 21(3), 253-264.

Florian, L. (2008). Inclusion: Special or inclusive education: Future trends. British Journal of Special Education, 35(4), 202-208.

Florian, L., \& Black-Hawkins, K. (2011). Exploring inclusive pedagogy. British Educational Research Journal, 37(5), 813-828

Florian, L., \& Spratt, J. (2013). Enacting inclusion: A framework for interrogating inclusive practice. European Journal of Special Needs Education, 28(2), 119-135.

Florian, L. (2014). Reimagining special education: Why new approaches are needed. In L. Florian (Ed.), The Sage handbook of special education (pp. 9-22). Sage.

Florian, L. (2015). Conceptualising inclusive pedagogy: The inclusive pedagogical approach in action. In J. Deppeler, T. Loreman, R. Smith \& L. Florian (Eds.), Inclusive pedagogy across the curriculum: International perspectives on inclusive education (Vol. 7). (pp. 11-24). Emerald Group Publishing. 
Florian, L., \& Walton, E. (2017). Inclusive pedagogy within the Southern African context. In P. Engelbrecht \& L. Green (Eds)., Responding to the challenges of inclusive education in Southern Africa. (pp. 167-180). Van Schaik Publishers.

Forlin, C., Loreman, T., Sharma, U., \& Earle, C. (2009). Demographic differences in changing pre-service teachers' attitudes, sentiments and concerns about inclusive education. International Journal of inclusive education, 13(2), 195-209.

Forlin, C. (2010). Teacher education for inclusion: Changing paradigms and innovative approaches. Routledge.

Hall, T. E., Meyer, A., \& Rose, D. H. (2012). Universal design for learning in the classroom: Practical applications. Guilford Publications, Inc.

Kameenui, E .J., Carnine, D. W., Dixon, R. C., Simmons, D. C., \& Coyne, M. D. (2002). Effective teaching strategies that accommodate diverse learners (2nd ed.). PrenticeHall.

Krischler, M., Powell, J. J., \& Pit-Ten Cate, I. M. (2019). What is meant by inclusion? On the effects of different definitions on attitudes toward inclusive education. European Journal of Special Needs Education, 35(4), 632-648.

Larsen, T. C., Holloway, J., \& Hamre, B. (2019). How is an inclusive agenda possible in an excluding education system? Revisiting the Danish dilemma. International Journal of inclusive education, 23(10), 1049-1064.

Loreman, T. (2017). Pedagogy for inclusive education. Oxford Research Encyclopedias, Education, pp.1-18. https://doi.org/10.1093/acrefore/9780190264093.013.148

Makoelle, T. M. (2014). Pedagogy of inclusion: A quest for inclusive teaching and learning. Mediterranean Journal of Social Sciences, 5(20), 1259-1267.

McIntyre, D. (2009). The difficulties of inclusive pedagogy for initial teacher education and some thoughts on the way forward. Teacher and Teacher Education, 25, 602-608.

McTighe, J., \& O’Connor, K. (2005). Seven practices for effective learning. Educational Leadership, 63(3), 10-17.

Morina, A. (2020). Approaches to inclusive pedagogy: A systematic literature review. Pedagogika, 140(4), 134-154.

Muthukrishna, A., Morojele, P., Naidoo, J., \& D'Amant, A. (2016). Access to education: Experiences from South Africa. In E. Iriarte, R. McConkey \& R. Gilligan (Eds.), Disability and human rights: Global perspectives (pp. 33-149). Palgrave Macmillan. 
Nind, M. (2005) Models and practice in inclusive curricula. In M. Nind, J. Rix, K. Sheehy \& K. Simmons (Eds.), Curriculum and pedagogy in inclusive education: Values in practice (pp. 1-12). Routledge.

Nunan, D., \& Bailey, K. (2009). Exploring second language classroom research: A comprehensive guide. Foreign Language Teaching and Research Press.

Pantić, N., \& Florian, L. (2015). Developing teachers as agents of inclusion and social justice. Education Inquiry, 6(3). https://doi.org/10.3402/edui.v6.27311

Pappano, L. (2011). Differentiated instruction reexamined. Harvard Education Letter, 27(3), $3-5$.

Putnam, J. (2009). Co-operative learning for inclusion. In P. Hick, R. Kershner \& P. Farrell (Eds.), Psychology for inclusive education (pp. 81-95). Routledge.

Republic of South Africa. (2015). Revised Policy on the Minimum Requirements for Teacher Education Qualifications. Government Gazette, 38487. Government Printers.

Sayed, Y., Carrim, N., Badroodien, A., \& Singh, M. (2018). Initial Teacher Education in and for the $21^{\text {st }}$ Century. In Y. Sayed, N. Carrim, A. Badroodien, Z. Macdonald, \& M. Singh, M. (Eds.), Learning to teach in post-apartheid South Africa: Student teachers' encounters with Initial Teacher Education (pp 1-25). African Sun Media.

Sharan, Y. (2010). Cooperative learning for academic and social gains: Valued pedagogy, problematic practice. European Journal of Education, 45(2), 300-313.

Shulman, L. S. (1986). Those who understand: Knowledge growth in teaching. Educational Researcher, 15(2), 4-14.

South African Council for Educators. (1997). Code of Professional Ethics. South African Council for Educators.

Thomlinson, C. A. (2003). Fulfilling the promise of the differentiated classroom: Strategies and tools for responsive teaching. Association for the Supervision of Curriculum Development.

United Nations Educational, Scientific and Cultural Organization. (2015). Education for All 2000-2015: Achievements and Challenges [Global Monitoring Report]. United Nations Educational, Scientific and Cultural Organization.

Walton, E., \& Rusznyak, L. (2020) Cumulative knowledge-building for inclusive education in initial teacher education. European Journal of Teacher Education, 43(1), 18-37. https://doi.org/10.1080/02619768.2019.1686480 